\title{
SCIENTIFIC DEVELOPMENT OF NOTIONAL DETERMINATION OF BASIC TERMS OF DEFENCE SCIENCE
}

\author{
Ivan Petrović, Milan Kankaraš and Krum Cvetković \\ University of Defence in Belgrade, Republic of Serbia
}

There is clear relationship between science and civilization. Development of science is determinated by the development of civilization. This is a reversible process of interdependence of science and civilization. Also, the genesis and development of civilization are monitored by conflicts among the tribal communities, and the emergence and development of the states, between citizens of them and nations. In essence, the development of civilization is directly related to the human ability to create, but also to destroy. In these conditions, conflicts arise and escalate into wars and the discovery of gunpowder and firearms in armed conflicts. Systematization of experiences from armed conflicts has enabled the creation of a unique scientific theoretical fund, which provides understanding of development of the uses of military units in armed conflicts.

As a result of the development of this fund military science or science of defence created and developed. Exponential technological development of weapons systems and military equipment (military asset) improves the manner of use of military units and significantly complicates the organizational and combat structure of the army. Complexity of the organizational structure of the military influences on the development of science of defence and the emergence of a lot of number of scientific disciplines from the specter of the indigenous science of defence.

In this paper it is presented a scientific review of the notional categorization of development of basic science of defense. In addition to the introduction and conclusion, the paper consists of two more parts. The first part deals with theoretical determination science of defence. In the second part it was given the classification of the science of defence and notional definition of the basic science of defence and their subjects and objects.

Key words: Science of Defence, Strategy, Operational Science, Tactics

\section{Introduction}

Tre he emergence of science, as a result of the development of epistemological method of thinking, inherent to the human race, is a consequence of the development of civilization, as well as qualitative differences between the human race and other living beings. 
Since the emergence of the first philosophical directions, such as Metaphysics (the essence of the existence of objective reality is in balance and stationary, and every movement is focused on establishing a new state of stationary between the phenomena) and Dialectic (the essence of the existence of objective reality is in movement and stationary is essentially a balance between the process of moving the phenomenon of objective reality), the development of civilization has enabled the creation of science of defence system. And while metaphysics formed the basis for the development of natural, dialectic enabled the development of social science.

There are many definitions of science. For example, according to the Dictionary of Serbo-Croatian literary language "Science is defined as a system of knowledge and laws of development of nature, society and thinking "(Dictionary of Serbo-Croatian literary language, book 3). According to another conception of "Science is a system of knowledge in a particular subject area. There is a perception that science is not a system of knowledge rather than activity, it is the striving of human to get closer to the truth about the world that surrounds us. According to Đura Sušnjić "Science is a distinctive method by which human being explains and understand the world around them and himself in the world [11]".

According to Momčilo Sakan "Science is systematized and substantiated knowledge of the objective world which is obtained through the conscious application of certain research methods [8]". Acceptable is the definition that science is a set of systematic methodological verified knowledge of a particular area of objective reality.

In accordance with the development of civilization thoughts originates and other science, whose object of study, or particular area of objective reality increasingly narrows. In those conditions science of defence are developed by military theorists. Their development is directly related to the development of technological solutions in the defence industry and military scientific thought, as an integral part of the intellectual elite of a society.

\section{Theoretical determination of Defence Science}

Defining science of defence is complicated from the point of application of different phrases in science theory. For example, science of defence is often called the military science (or art of war). Namely, taking into consideration the military and doctrinal orientation of the Republic of Serbia, phrase science of defences is more acceptable than phrase military science.

However, this replacement in terminology can become inadequate bearing in mind that the defence of the Republic of Serbia is realized by engaging the available human and material resources of the Serbian Army and other forces of defence. These resources engage to protect the sovereignty, independence, territorial integrity and security (Defence Strategy of the Republic of Serbia, Belgrade, 2008, p. 13).

In The Law on Defence it is noted that "The System of Defence is the part of national security and a unique form of organization and preparation for the performing of defence tasks, implementation of measures and actions for the needs of citizens, public institutions, companies and other legal entities for the use of the Army of Serbia and other forces of defence during the war and emergency situations". So the defense is manifested by the performing of functions of the Army, as well as another defence forces. Taking 
into consideration aforementioned it should be noted that, during the existence of complex security threats to the state, the main tasks will be performed by the Army, which justifies the use of terminological phrase military science from the logical and methodological point of view.

Throughout history, numerous theorists who have attempted to define and classify the science of defence. The most of these efforts were aimed at identifying areas of objective reality which would represent the subject of science of defence, as well as the basic criterion for their classification.

According to Momčilo Sakan, the basic criteria for the classification of science of defence are [ 8]:

- generality,

- the nature of the object of science,

- connections between the science and disciplines,

- rationality,

- importance,

- state of current practice,

- pragmatism,

- similarities and differences,

- belonging to the indigenous science and

- development of constituents of science.

As well as other, military science has developed the following constituents:

- subject,

- object,

- theory,

- methods and

- language.

From the point of view of theoretical determination the subject and object of science of defence are particularly important. Specifically, according to Vucinic, the subject of science (war, armed warfare, armed forces, etc.) is something what connects the science dealing with military issues (defence complex in the system of military science or science of defence). The basis, cohesive factors (inner circle) of the system are:

- strategy (war),

- operational science and

- tactics.

Other science (military sociology, military history, military economy, etc.) are on the outer circle of the system [13]. It should be noted that the classification (military) strategy, operational science and tactics, as a discipline of the art of war, is outdated, and it is directly related to the development of scientific thought and civilization in all spheres of social life.

One example of classification of science of defence (military science) is shown in figure 1 .

\footnotetext{
${ }^{1}$ According to M. Sakan there are three reasons why phrase the art of war can not means the science of defence. The first reason is that this phrase is associated with skills (not on science). The second reason is the logical character because it reminds that the war has some skill, which is not possible (the war is not the subject). The third reason is that it is associated with a complex social phenomenon, not the armed warfare as an object of science of defence [9].
} 


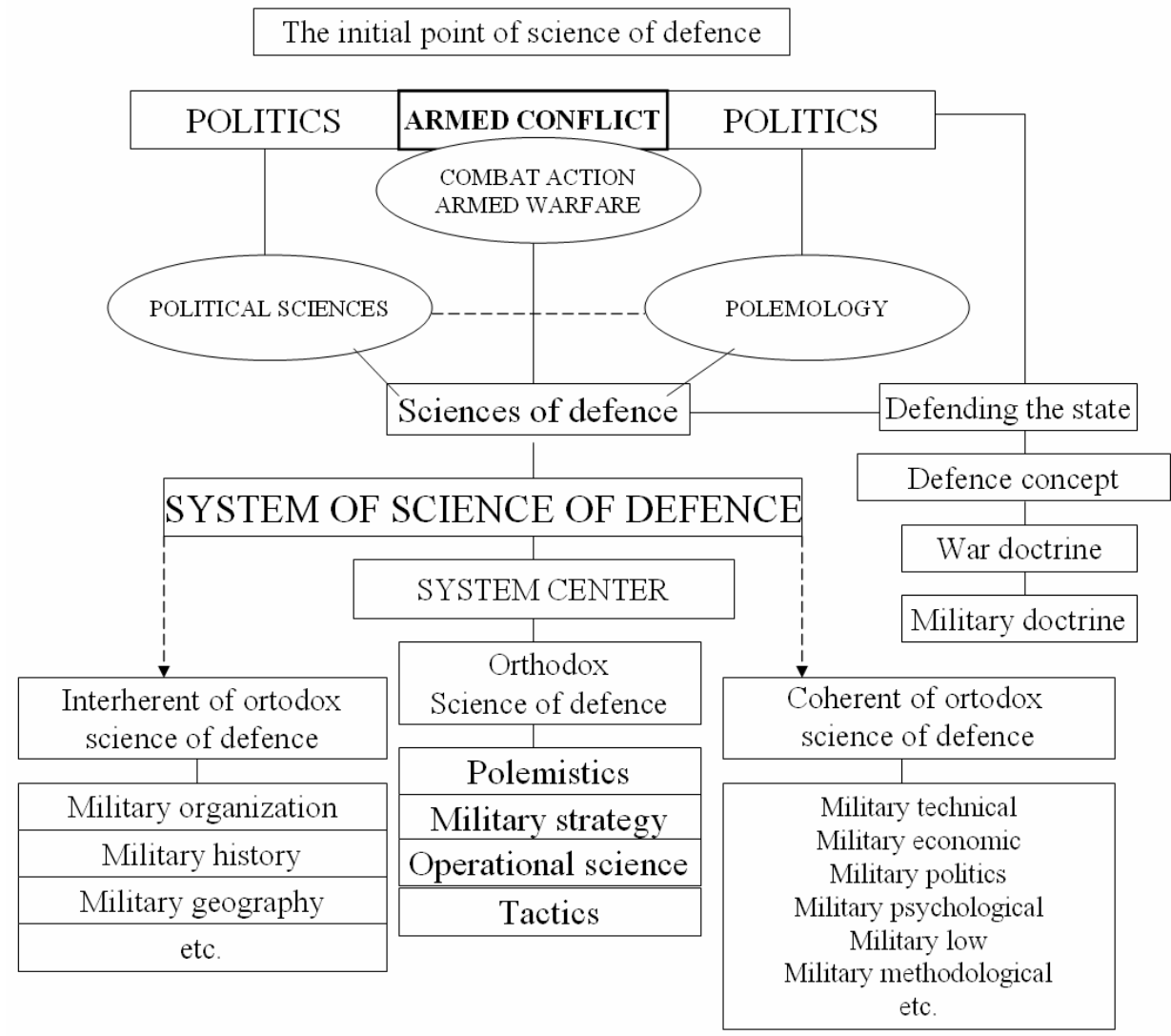

Figure 1 - Classification of science of defence (according to criteria spheres of social life and activities in armed conflict)

Those phrases originate from the ancient times when a scientific and professional knowledge, which is related to the practical operation, termed skills. For example, logic was called the art of thinking, rhetoric was the skill of speech, math was called skill of computation. At present those "skills" have become science, and most of them and system of science, based on scientific facts which are proven applying the scientific methods, and with developed theory and language.

According to Momčilo Sakan, the science of defence can be defined as "The systematic and substantiated knowledge about armed warfare which were gathered conscious application of certain research methods [ 9 ]".

Acceptable definition is that the science of defence is a set of systematic methodological verified knowledge about armed warfare as the main content of the armed conflict.

Taking into consideration the numerous disagreements about the object of indigenous science of defence between the Western and Eastern military theorists (after the 
Second World War Yugoslav Military thought accepted the Eastern classification of the indigenous science of defence on tactics, operational science and (military) strategy. Unlike the East, to the West there is a dual classification of the indigenous science of defence on tactics and (military) strategy. Those disagreements were significantly influenced the determination of the object of science of defence in this region.

Definition of the object of science of defence requires previously the theoretical determination of terms armed conflict and operation.

\section{Theoretical determination of Operation, Armed Conflict and Armed Warfare and the logical relationship between these terms}

According to the Doctrine of Operations, armed conflicts represent a process of mutual destruction of the conflicting adversaries. They can be a result of the conflict of political interests between states, within states, or a result of religious and ethnic tensions, damaged elements of national force, social collapse, shortage of natural resources, organized crime and corruption. Acceptable definition of armed conflict is that it represents the military - technological social phenomenon (genus proximum - senior notion in relation to the term that is defined) in which the mutual destruction of two or more adversaries to the conflict realize political, economic, military, diplomatic or confessional aims of the conflicting adversaries, which could not be achieved by other activities (diferencia specifica - specific differences notion which is defined in relation to all the other terms contained in the senior notion) [4]. For the armed conflict is characteristic regular (legal) use of armed force in achieving the aims. In recent decades, the traditional armed conflicts, which have historically been mostly symmetrical, have got a totally new dimension [4]. Namely, the symmetry, from the point of view of military force, economic, political and diplomatic influence of conflicting adversaries in recent decades slowly becomes dissymmetry, and the main role in achieving conflict aims takes Air Force and Air Defence (AFAD). Namely, not only that air and air defense operations, i.e. forces that carry out operations, influence the outcome of contemporary armed conflicts, but also at the same time, they change the basic characteristics of armed conflicts, with particular emphasis on asymmetry and nonlinearity which are new characteristics of contemporary armed conflicts [6]. This is the consequence of the growing imbalance between conflicting adversaries in components that determine the outcome of the conflict (political, economic, military, diplomatic component). The genesis unsymmetrical armed conflicts constitute an appropriate impulse for inferior side in the conflict to find a new strategy of caring out armed conflict. As a consequence of that, the last two decades, marking asymmetric armed conflicts, where the relatively small forces with fundamental planning have achieved effects of strategic proportions. Asymmetry, as a characteristic of modern armed conflicts, is characterized by the precise political, economic, diplomatic, technological and military imbalance between the conflicting adversaries [3].

The main content of the armed conflict is armed warfare. It represents the highest form of manifestation of armed destruction conflicting adversaries [1]. The armed warfare qualitatively and quantitatively represents the set of all other forms of its manifestation 
(individual combat actions and reactions and other activities, combats and battles). According to the Doctrine of Operations, armed warfare as the main content of the armed conflict is a social phenomenon and reversible processes in which conflicting adversaries plan, prepare and perform operations. Acording to the criterion of importance of aim that is achieved, the basic levels - forms of armed warfare are classified in: battle, combat, individual combat actions and reactions and other activities.

The battle is the highest level of armed warfare. In battle there is a conflict the main forces of conflicting adversaries. The battle decisively influences the period of armed conflict war or its outcome. Armed conflict - war can be started and finished with one battle, but usually armed conflicts consist of more than one battle. In essence, from the point of scientific and professional knowledge, as well as in the context of history, all armed conflicts carried out during development of civilization of human society are recognized through their concrete forms of manifestation. Namely, for example, the first of all, what the First World War on the territory of the Kingdom of Serbia makes it recognizable, are specific forms of manifestation of armed warfare, such as the Battle of Cer, Battle of Drina or Kolubara. Also whether the Second World War was remembered on this kind that there was no famous battles such as Battle of Staljingrad, Battle of Kursk, etc.

The combat consists of several individual combat actions and reactions and activities. It decisive influences on the outcome of armed conflict on tactical level [5]. In the combats the tactical units or tactical joint stuctures are usually engaged. Combat is the next level of manifestation of the armed warfare. It also represents a specific form of armed warfare and can be carried out between the conflicting adversaries individually or as a part of battle [5].

Combat action and reaction and activities are basic levels of warfare. In those levels of warfare there is a massive conflict of smaller conflicting adversaries in carrying out assigned missions and tasks [1]. These levels of warfare represent the smallest form of manifestation of armed warfare and can be carried out between the conflicting adversaries individually or as a part of combat or battle.

Taking into consideration aforementioned, armed warfare and its forms of manifestation are reversible processes and for their performing are required at least two conflicting adversaries, which in these forms, prepare and conduct operations [5]. In fact, as armed warfare and the forms of its manifestation are reversible process, and operations that are performed by the forces, are one-way process. Namely, each side in the armed conflict performs its operation determined by events in a concrete form of armed warfare, as well as the operation performed by the other side (no specific form of armed warfare without at least two operations) [5]. Historically, military theorists have, from the time when Mosor (Polish theorist) began to use this term in military terminology, tried to define the operation. On the one hand the Eastern school, led by the military theoreticians of the former Soviet Union, who considered the operation as a reversible process, and on the other hand considering the operation as a military term, pragmatically oriented Western theorists proceeded from the standpoint that it is a one-way process (well - known Boffres Cclassification development operations through the historical period [ 12 ]).

Influenced by Eastern theoretics, during the expansion of the development of military theory in the former Socialist Federal Republic of Yugoslavia, the operation is considered as the highest form of combat actions, which essentially represents reversibly process. For that period, the appropriate definition of operation is that it is the highest and most complex 
form of organization and performing of armed warfare which according to unique plan in a particular space in a particular period of time, unify and direct the combats, tactical and other combat and non-combat actions and other activities of the armed forces and other defence forces aimed at achieving strategic and operational objectives. This definition puts the operation in the same logical level with the combats and warfare as well as, i.e. in the level of reversibly processes. After the dissolution of the former Socialist Federal Republic of Yugoslavia and the restructuring of the whole System of Defence, including the Army, there were also changes in the way of understanding the operation of the military theory. According to the Doctrine of Operations, the operation is notionally defined as a set of combat and/or non-combat activities, movements and other actions to be taken by a unique concept aimed at achieving the overall objective of different characters. They are carried out independently and in coordination with other defence and allied forces.

In essence, the operation is complex, planned and prepared process in which the available resources in a particular space and in a particular period of time in accordance with unique plan achieve the objectives of different characters. Acceptable is the definition of operation as a one-way process in which one side in the conflict is prepared and performed combat and non-combat activities, actions and movements according to an unique plan (operational plan, operational orders) in a particular operational environment aimed at achieving the set objective and final desired effects [5]. The aforementioned definitions indicate that the operation is a one-way process that is not in the same logical level with the forms of armed warfare, i.e. only by mutual activity - the interaction of at least two forces engaged in at least two operations can be achieved by a specific form of armed warfare, notionally defined as a battle, combat, or combat actions and reactions and other activities, depending on the character of the operations of the conflicting adversaries. The main determinant which influences the performance of the operation is the operational environment. According to the Doctrine of Operations operational environment is defined as a set of conditions in which forces are engaged in operation in accordance with commander's decision, and which have the influence on outcome of operation. It is acceptable and the notional definition of the operational environment as a set of components that directly determine the conditions of preparation and performing of operation [2]. According to the criterion of one-way character of the process, realized by one of the conflicting adversaries, levels of operations are determined on: campaigns, main and support operations.

The campaign brings together more operations aimed at achieving military-strategic objectives and final desired effects. Within the campaign, according to importance, one operation is planned, prepared and performed as the main operations of the campaign, and other operations are ancillary (support operations). The definition of the campaign is as follows: The campaign is a set of all combat and non-combat activities, movements and other actions that one side in the conflict performs according to the unique concept aimed at achieving objective and final desired effects during the (armed) conflict (political, economic, military, confessional objective).

The main operation in the campaign, it is always supported by support operations. The main operation is planned, prepared and carried out aimed at achieving objective of the campaign. On the military strategic level, the result of planning determines the main operation within the campaign. It is acceptable definition of main operation as the highest and most complex oneway process in a campaign that represents the set of all combat and (or) non-combat activities, 
movements and actions that one of the side of the conflict performs according to the unique concept aimed at achieving the strategic objective during the (armed) conflict.

Support operations are carried out in support of achieving the main objective of the operation or of the main operation in campaign, as well as to create conditions for the transition from one operation to another. They are performed before the combat or non-combat operation, during or after this operation. It is acceptable and theoretical definition of support operations as one-way process, prepared and performed before or during or after main operation which represents a set of combat and (or) non-combat activities, movements and other actions to be taken by one side in the conflict according to the unique concept aimed at achieving certain the tasks arising from the target basic operations.

Taking into consideration aforementioned it can be concluded that the operation is a oneway process, and that the armed warfare and its levels are reversible processes. There is no armed conflict, i.e. armed warfare as its main content, without at least two combat campaigns of conflicting adversaries, as there is no battle, combat, combat action or reaction and other activities, without at least two of the main or support operations of conflicting adversaries.

In figure 2 it is shown the relationship between the operations and the levels of armed warfare in armed conflict. The operations, which are prepared and performed by the conflicting adversaries represent dialectical unity and opposite which results in achieving a new quality in the armed conflict, and the specific form of armed warfare.

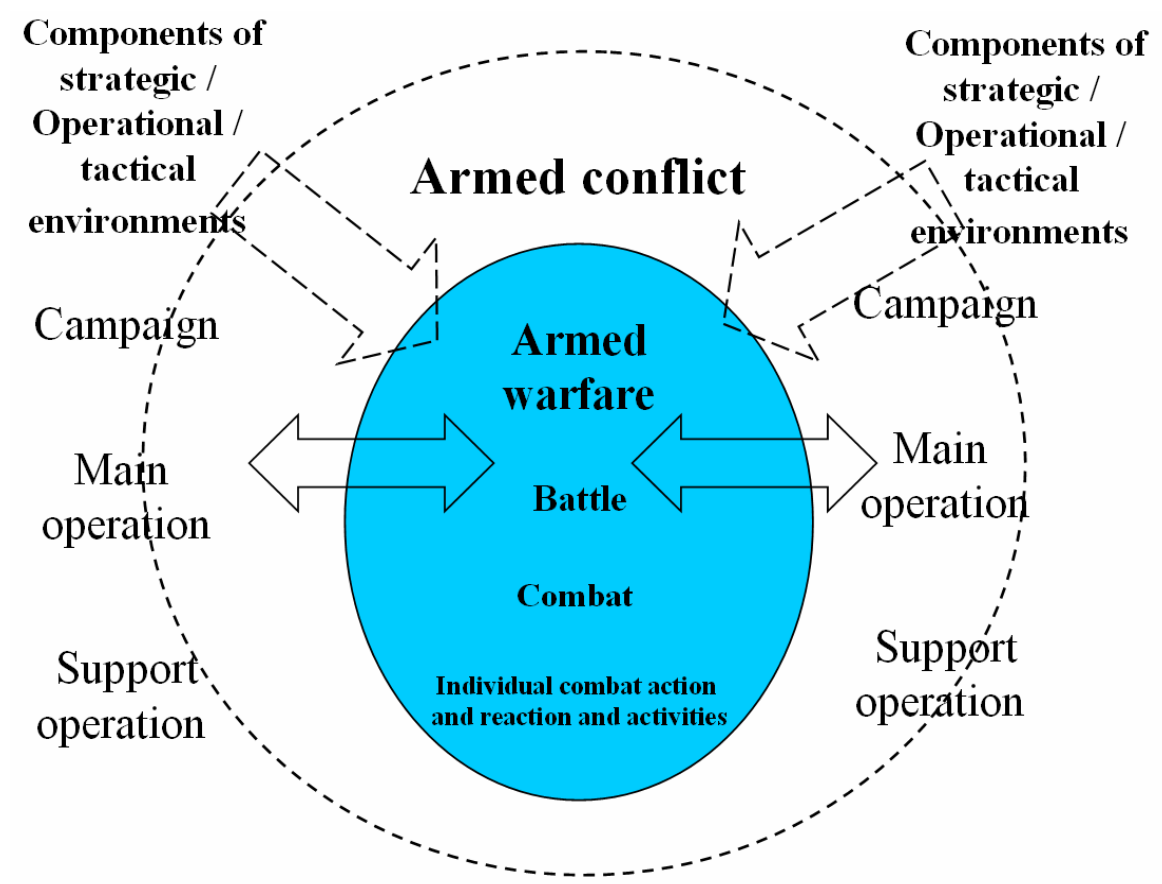

Figure 2 - Relationship between operations and concrete forms of armed warfare 


\section{Notional determination of Military Strategy, Operational Science and Tactics in relation to the Subject and the Object of science}

In accordance with the definition of the Sakan object classification of indigenous science of defence on armed warfare and its concrete form - forms of manifestation in the armed conflict, it is acceptable that the object of military strategy is armed warfare as a whole, the object of operational science is a battle (i.e. the highest concrete form and a reversibly process of performing armed warfare), and the objectc of tactics are combat and combat actions and reactions and other activities as the smallest levels of armed warfare.

In these particular forms of armed warfare a multitude of activities through a series of combat and non-combat actions in combat and non-combat operations (as a one-way process) are carried out by Army and other defence forces. Combat actions and reactions as fundamental, unique specificity of actions of Army Forces, manifest themselves through combat operations in all its contents.

Bearing in mind aforementioned classification of the object of indigenous science of defence can be logically valid and executed according to the one-way process in which the military activity is implemented.

According to this criterion, the object of military strategy would be the campaign, operational science the main operation within campaign and the support operations of operational importance, and the object of tactics would be the main and support operations of tactical importance.

Taking into consideration aforementioned it leads to a new correlation between constituents of science. Namely, it is introduced the term subject of science. In science, in general the meaning of subject of science considers entire reality, or a set of phenomena, and in the social science - a set of social events. Also, the subject itself can be expressed as a part of continent, or a separate entity consisted of special parts [8]. In accordance with this perception of subject, the object is manifested as a part of the subject which can be reaserched.

Historically, at the beginning the subject of science of defence was war, than armed warfare or military forces. For example, S. Ilic believes that the subject of science of defence is the war as a whole, M. Vučinić - war, armed warfare, armed forces, and according to G. Fox it is a set of material and social phenomenon of armed warfare [13].

According to the criteria of the organizational structure it is acceptable that the subject of indigenous science of defence (military science) should be military activity in the narrow or entire defence activity. Based on this criterion, the subject of military science is entire military activity, operational science Army activities of operational units, and the object of tactics are activities of units of tactical level of organization (activities units and joint forces to the brigade level of organization). In accordance with the aforementioned, notional definition of science of defence would be the following: Science of defence is a set of systematic methodological verified information on military activities.

Therefore, according to this criterion, (military) strategy is a set of systematic methodological verified knowledge of entire military activity. Operational science represents a set of systematic methodological verified information on military activities of the operational units, and tactics is a science that represents a set of systematic methodological verified information 
on military activities at the tactical level of organization. Classification of indigenous science of defence according to the object - subject of science is presented in figure 3.

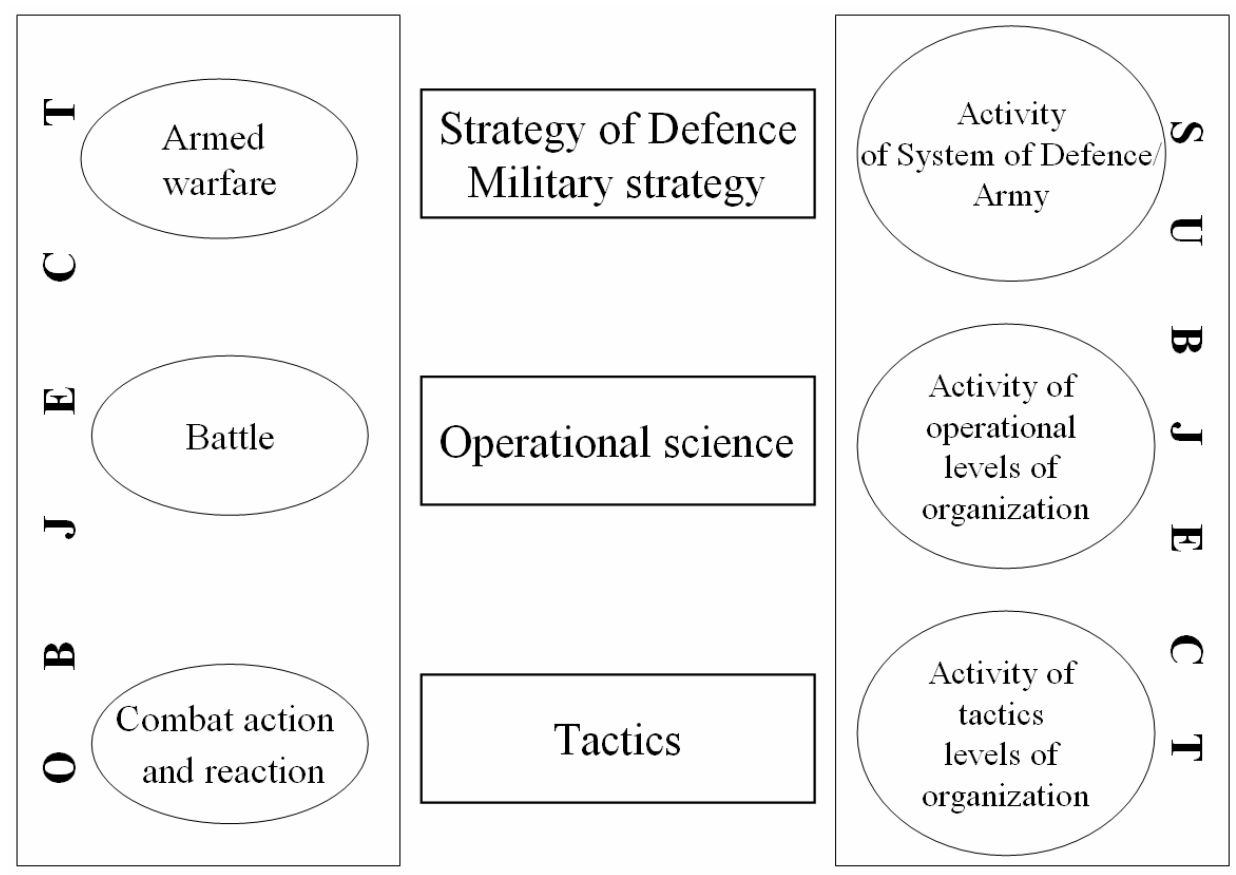

Figure 3 - Classification of indigenous science of defence according to the object - subject of science

Taking into consideretion that the subject of science are armed combat action and reaction and other activities, combat and battle, indigenous science of defence would define as follows:

- Military strategy could be defined as a set of systematic and methodologically verified information of entire activities of the Army in the armed warfare.

- Operrational science could be defined as a set of systematic and methodologically verified knowledge of activities of the Army in the battle, which represents the highest level of armed warfare.

- Tactics is a indigenous science of defence which represents a set of systematic and methodologically verified knowledge of activities of thr Army in the combat action and reaction, as the basic levels of armed warfare.

However, those definitions do not include completely engagement of the Army Forces in the joint operations of operational level of organization consisted of components of branches and services units of tactical levels of organization (a squadron, division or battalion), and in accordance with aforementioned they do not include complete object of tactics. 


\section{Conclusion}

Definition and classification of the science of defence is a problem that is as old as the theoretical systematized knowledge of armed conflict. Taking into consideration that the area of objective reality called an armed conflict exists as a social phenomenon determined by the development of civilization, it is necessary to define armed conflict on an appropriate scientific level. The exponential development of science and technology and continuous divergence of science at all classification areas influences the need for precise determined theoretical definition of the science of defence. Only this approach will provide a better understanding of the armed conflict and specific forms of its manifestation from the scientific point of view.

\section{References}

[1] Gordić M., Petrović I., Raketni sistemi u odbrani malih država, MC "Odbrana", Beograd, 2014.

[2] Gordić M., Petrović I., Cvetković K., Uloga raketnih jedinica za protivvazduhoplovna dejstva u operaciji kontrole i zaštite vazdušnog prostora [The Role of Air Defense Missile Units in the Air Space Control and Protection], Vojno delo 66 (2), 2014.

[3] Gordić M., Cvetković K., Petrović I., Uticaj vazduhoplovnih i protivvazduhoplovnih dejstava na fizionomiju vođenja savremenih oružanih sukoba [Effect of Air Force and Air Defense Operations on the Physiognomy of Contemporary Armed Conflicts], Vojno delo 65 (2), 2013.

[4] Petrović I., Konceptualni model sistema protivvazduhoplovne odbrane Vojske Srbije, PhD thesis, VA, Univerzitet odbrane u Beogradu, Beograd, 2013.

[5] Petrović I., Cvetković K., Stojiljković Z., Teorijsko određenje vazduhoplovnih i protivvazduhoplovnih dejstava [Theoretical Determination of Air Operations and Anti-Air Operations], Vojno delo, 67 (4), 2015.

[6] Petrović I., Kankaraš M., Cvetković K., Significance and Prospects of the Development of Air Defence System. Vojno delo, 67 (6), 2015.

[7] Pečujlić M., Milić V., Metodologija društvenih nauka, SL SFRJ, Beograd, 1991.

[8] Sakan M., Vojne nauke, VIZ, Beograd, 2003.

[9] Sakan M., Metodologija vojnih nauka, VIZ, Beograd, 2005.

[10] Šešić B., Opšta metodologija, Naučna knjiga, Beograd, 1974.

[11] Šušnjić Đ., Metodologija, Čigoja, Beograd, 1999.

[12] Teorijski i praktični aspekti savremenih operacija, Vojno delo, 53, 2003.

[13] Vučinić M., O sistemu vojne nauke, VIZ, Beograd, 1971. 